Article

\title{
Information System Purchase and Integration Contingencies When Companies Merge
}

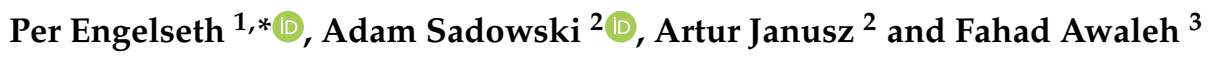 \\ 1 Tromsø School of Business and Economics, Narvik Campus, UiT the Arctic University of Norway, \\ 8514 Narvik, Norway \\ 2 Institute of Logistics and Informatics, University of Lodz, Rewolucji 1905 r. 37, 90-214 Lodz, Poland; \\ adam.sadowski@uni.lodz.pl (A.S.); ar.janusz@gmail.com (A.J.) \\ 3 Kristiania University College, Prinsens Gate 7-9, 0107 Oslo, Norway; Fahad.Awaleh@kristiania.no \\ * Correspondence: pen008@uit.no
}

Citation: Engelseth, P.; Sadowski, A.; Janusz, A.; Awaleh, F. Information System Purchase and Integration Contingencies When Companies Merge. Sustainability 2021, 13, 8223. https://doi.org/10.3390/su13158223

Academic Editor: Donato Morea

Received: 15 June 2021

Accepted: 20 July 2021

Published: 23 July 2021

Publisher's Note: MDPI stays neutral with regard to jurisdictional claims in published maps and institutional affiliations.

Copyright: (c) 2021 by the authors. Licensee MDPI, Basel, Switzerland. This article is an open access article distributed under the terms and conditions of the Creative Commons Attribution (CC BY) license (https:/ / creativecommons.org/licenses/by/ $4.0 /)$.
Abstract: This study grounds empirically the purchasing and further integration of an implemented information system set in the frenzied context of a corporate merger. A single longitudinal case study from the Norwegian pelagic seafood industry provides a detailed long-term account of developing the information system prior to, during and after a merger in the seafood industry that relies on wild catch. It is characterised by high dependence on features of nature and society to secure sustainable production. Contingency theory together with a process view of production reveals how interactions unfold over time to develop the new unified information system. Features of integration, interaction and interdependency represent different facets of information system purchase and development. The merger process represents an abnormality for the organisation as a continuous entity. Information system development in the case, therefore, takes place in a weakly integrated network of merging firms with severe time constraints. Given high uncertainty, solutions emerge through interaction. Deterministic optimisation is, in this context, a fluffy managerial dream. Normally, information system purchase and information system development involve reciprocal interdependencies involving mutual adjustments through intensive technologies and tight interaction among all parties involved. The coercive behaviour of management seeking efficiencies overrules these planning ideals. This indicates that purchasing, in a corporate merger context, is complex and approached as a complex system in a network. Solutions used in this approach originate because of emergent-networked interaction.

Keywords: corporate merger; information system development; interdependencies; collaboration; contingency theory; seafood industry

\section{Introduction}

A corporate merger involves the integration of different firms and their various business functions within a short time frame. It is a clearly challenging project organisation task given its limited period. In this context, information system (IS) development is a major and challenging technical and organisational undertaking when companies merge. This study directs attention to the issue of purchasing in this time-limited organisational context.

Henningson et al. [1] carried out an extensive literature review on IS integration in contexts of both corporate mergers and acquisitions, including (1) the merger and questions context, (2) the relational fit, (3) the human side, (4), and preconditions of IS integration and (5) time pressures. These aspects constitute the backdrop of this investigation. Its purpose is to provide an empirically grounded and detailed conceptual understanding of networking involved in a purchase associated with IS development when different companies producing more or less the same type of product merge-a horizontal form of integration. Although firms may be of different size and information technology (IT) proficiency, this means that the merging companies, from a functional viewpoint, should have 
relatively comparable ISs. This research empirically demonstrates how interdependent firms integrate and interact to economically develop their ISs in a time-limited organisational context triggered by the corporate merger decision. This development process encompasses a range of purchase-related interactions supporting the integration of several heterogeneous information systems from different companies undergoing a merger, in an industry dependent on wild-catch, plagued by economic, societal and natural concerns.

The topic is of interest, fundamentally, because the issue of purchasing directly associated with mergers is weakly conceptualised. At a more general level, Wijnhoven et al. [2] point to the lack of publications addressing the issue of IS development and corporate merger despite their frequent occurrence. Furthermore, the existent literature on the subject is now rather old and includes Buck-Lew et al. [3] and McKiernan and Merali [4] who discuss the importance of the topic of corporate mergers. Papers on IT and corporate mergers also include Stylianou et al. [5], Giacomazzi et al. [6] and Robbins and Stylianou [7] who propose factors that affect the IT integration success, while Alaranta and Henningson [8] propose methods for planning IS integration. From the network perspective, corporate mergers represent external integration, a change in the network from relational governance to a single organisational hierarchy [9]. Such change in the supply network structure may involve horizontal or vertical integration $[10,11]$. Vertical integration takes place when companies organised as actual or potential suppliers or customers choose to merge. In cases of horizontal mergers, the process is more or less similar, including actual or potential competitors that choose to merge.

The case study on which we base our analysis is published by Alm et al. (2009) in a conference paper. This study focused on the wider topic of IS development in the corporate merger context. Alm et al. [12] applied discourse theory [13] together with actor network theory [14] to explicate five major discourses, setting the agenda of the IS development in a corporate merger context in the seafood industry in Norway. This study, although encompassing a broader perspective, had a rather focused approach to considering features of organisational discourse in the studied merger context to develop the required new IS. Probing for discourses, the aim of this paper according to Alm et al. [12] was not an academic search for "hidden meanings", but rather uncover to exhibit "... as unbiased as possible the actual discourse regarding information system development" (p. 371). While the study conducted by Alm et al. [12] focused on information system development, this paper, based on the same data, concentrates on another managerial problem associated with information system integration, namely, the fact that this system development is also a purchasing issue for merging and newly merged firms. This implies the use of a different literature base to analyse the same data presented in the report by Alm et al. [12]. The studied case involves horizontal integration, and it is different from vertical integration where complimentary firms choose to merge to secure flows of goods and services to their markets. A corporate merger is an inter-organisational undertaking, commonplace also in the food industry, which this case study concerns. In this study, we revisit the same data applied by Alm et al. [12] to provide an alternative analysis of particularly the purchasing process involved in IS development when companies merge.

This study focused on purchasing to support sustainable IS development. Similar to the study by Janusz et al. [15] on sustainability in a biotechnology research and development project, this is a longitudinal case study. This secures some degree of a long-term understanding of this development embedded in an industry-driven equally by economic, societal and environmental concerns. We use the framework developed by Janusz et al. [15] to focus on features of purchasing as a process in a networked industrial context. This case study (ibid.) principally merged concepts from three lines of thinking: (1) "integration" from fundamental types of supply chain management literature; (2) "interdependencies" from Thompson's [16] contingency theory; and (3) "interaction" from industrial marketing and purchasing group (IMP) literature. The study of Janusz et al. [15] focused on commercialisation through stakeholders' involvement in the industry, technology transfers from universities, government policies and their common efforts, drivers, barriers, 
benefits, impact and contribution to regional development in order to develop a better waste management system in Poland. The following research questions are founded on the framework developed by Janusz [15] concerning how interaction is associated with integration variation in this studied project organisation managing IS purchase and system implementation in a corporate merger context:

1. What are the network interdependencies?

2. How and why does the level of integration change in the network?

3. What characterises interactions throughout the period of the project?

4. How does the organisational context characterised by integration and interdependency impact interactions in carrying out the IS development project?

We accordingly move to analyse the context of the five discourses revealed in the study by Alm et al. [12] as features of "interaction" in the context of "interdependency" and "integration". Discourses in this framework are thus seen as revelations of "interaction". Thereby this study provides a partial context-related explanation as to the character of the revealed discourses discussed by Alm et al. [12].

\section{Frame of Reference}

\subsection{IS-Related Purchasing When Firms Merge}

Purchasing represents one of many functions involved in a corporate merger. It is, in essence, a disruption of a developed supply chain order, a developed structure characterised in part by its level of integration as well as interdependencies. In the studied case of horizontal integration, interdependency is mainly competitive since all the merging firms are alternative suppliers of the same customer base. Similarity is a major feature of the studied firms. Therefore, variation concerns features of the individual firms, such as their size, competence, economic standing, knowledge base, etc. Their interdependency varies in relation to such actor features. In cases of corporate mergers, the organisational context of production operations is subject to a radical change. Given that the technical facilities remain the same in the merged firm, the corporate merger does not change the structure of logistical flows. It is at the level of exchange between firms that the change occurs since, through the merger, transactions are handled by one firm rather than many. This disruption in how the firm is managed means that the IS needs to be adapted to a new way of purchasing, production and sales management.

In this case, the focus is directed to purchasing as a complex process to support IS development, not the regular purchasing function of a merged firm. While Henningson et al. [1], in their literature review, focus on IS integration as an outcome, this research focuses on the process of organising a new IS regardless of the "integration" as an outcome. We do not consider the "success" of this integration project, rather we seek to see how it works, good or bad. IS purchase is instead considered as an emergent phenomenon where the outcome always varies in more or less unpredictable ways. We apply a processbased view in this study providing a case description stretching over a prolonged timeline. Purchasing an implementation, taking a process view, is thus associated with the new IS development project is then considered an emergent phenomenon [17], also in line with Orlikowski and Yates [18] who conceptualise time and timing in a comparable manner, as a mixture of objective and subjective meanings. This implies a process-focused view of purchasing related to this IS development.

\subsection{Interdependency}

"Interdependency" focuses on why networked actors collaborate on developing a new IS in a corporate merger context. It stakes out why actors who collaborate in order to produce systemically need each other [16]. Interdependency is a structural supply chain characteristic. Parsons [19] states that the prime challenge of organisations is coping with uncertainty, whereas the level of complexity in production, management and environment affects this. Interdependency is relevant on all of these organisational levels involving (1) management, (2) production and (3) network organisational culture. Interdependency is 
a feature of a network structure. It may change over time. Over time institutionalised production emerges as measurable patterns of interaction. Ford and Mouzas [20] assume these are dynamic because they are the result of choices made by actors in the network, which also means that a network structure may change, albeit at a slower pace than a production process. Janusz et al. [15] (p. 464) state that "the institutional aspect of networks is key to understanding its interdependencies; it is perceived, and interdependency is an important perception held by various actors in a more or less collective network organisational structure". The quest for a corporate merger is organisationally complex since it involves a wide range of factors including the ISs of different companies. These ISs are complex in themselves. Furthermore, a corporate merger is, to some degree, engineered to coordinate the use of production technology in different merging companies. In addition, the merger process integrates diverse organisational cultures. Thus, even though a corporate merger is a planned process, the organisational complexity, together with its process dynamics, entails that carrying out a corporate merger involves uncertainty. In the study, IS development is viewed as a form of production in a project organisation.

\subsection{Integration}

The next step to consider is "integration". This is an important aspect of the industrial network structure. It is commonly applied to describe systemic features of a supply chain as regards how well actors are aligned, which affects how activities are coordinated. In this case, we study five merging companies striving to develop their IS through networking. This is not a clear systemic process, as both functionality and system borderlines (which actors/firms are participating) remain unclear. In this study, we speak of a "network" rather than a "chain" as the context for purchase aimed at supporting IS development. At a general level, Wijnhoven et al. [2] and Mehta and Hirschheim [21] address strategic alignment issues regarding IS in relation to merger and acquisition strategies in business practice. In this study, we view integration similarly to Janusz et al. [15], as a feature of a network structure, an outcome of interaction that influences, and/or is influenced by, interdependencies. More or less heterogeneous actors constitute the industrial network. It is in this network structure that actors do business with each other or compete with each other based on perceptions of degrees of complementarity [22].

"Integration" conceptually reflects how well different heterogeneous resources fit one another when combined to produce. In such a network, integrated resource constellations support activity coordination. Integration provides guidance in analysing why production either works smoothly as a process or results in failure. Purchasing is a process impacted by integration in a network. In this case, two aspects of integration might be considered. First, the integrating effort a corporate merger itself presents. Second, the degree to which the IS development project, this form of production, is supported by exhibited levels of integration. It is this second level that is the focus of this study. This integration effort is a slower structural change in the context of interaction. Integration represents seeing resource complementarity and harnessing the coercive behaviour inhibiting this pool of resources in a network to better support a coordinated production process (in this case, IS development). This integrating task is, however, challenging, since a network consists of many business relationships. "The manager becomes someone who must operate within multiple dependencies" [20] (p. 31). This complexity is, as in the case study by Janusz et al. [15], the reasoning for doing a longitudinal study, following the timeline of development as a narrative rather than analysing the immense complexity associated with the integration of a vast quantity of heterogeneous resources over the project time frame. From a supply chain management (SCM) perspective, with its focus on seeking economies through integration and better collaboration, IS development is a key enabler of effective collaboration [23]. The question remains as to how integration is carried out in the IS development project and to what degree integration actually supports quality interaction and the actual production of the new IS system of a merging company. 


\subsection{Interaction}

Interaction, in this case, characterises the networked and therefore emergent nature of IS purchase and development activities in a functional corporate merger context. Thompson [16] (pp.101-102) states that " ... human action emerges from interaction of (1) the individual, who brings aspirations, standards, and knowledge or beliefs about causation; and (2) the situation, which presents opportunities and constraints". In a project setting such as in this case study, networking over a limited period should display particularities regarding production improvement in such networks. From a network approach, production comprises activities whose inherent aspect is the interaction among people. Håkansson and Johanson [24] (p. 43) state that "networks are, by their very nature, in imbalance". This complexity is very much due to interaction. One of the key propositions emerging from the empirical research by Cantu et al. [25] is that "solutions (i.e., resource combinations) always emerge as a consequence of interaction among actors. This interaction makes the actual combination dependent on the web of actors involved and, therefore, difficult to predict" [25] (p. 148). In this study, purchasing is analysed as a process supporting the IS development in a corporate merger context. Network structure is characterised by interdependencies and integration influences this.

\subsection{A Conceptual Model on Purchasing Complexity}

The corporate merger is a project organisation form. It, therefore, has a finite space when following a timeline to describe a merger as an activity. Within this time limitation, interdependency is not associated with the daily production of fish for export, but with the creation of a new IS. This development takes place in the context of a company carrying out physical distribution meaning interdependency is predominately sequential. We propose that interdependency in the project is different from normal production. We propose it resembles more a service-based organisation, implying that either pooled or reciprocal interdependency is predominant [26]. In the case of IS development, in the short time frame allocated to such development, uncertainty is strong, and, accordingly, it principally resembles a "value shop" configuration [26]. This implies reciprocal interdependency should be predominant in this case.

Following Thompson [16], intensive technology supports activities in cases of high reciprocal interdependency. This means that interaction, in this service production, consists of manual mutual adjustments characterised by problem solving and learning. Also, in services, pooled interdependency is frequent. This involves, following Thompson [16], the use of mediating technology rooted in resource standardisation supporting automated interaction. Increasing automation means that actors may seek to standardise processes to reduce the relatively costly and easily wasteful intensive form of interaction. Finally, IS development in the case of a corporate merger should expectedly be an IS that supports the use of long-linked technology, the flow of seafood products through planning and levelling or buffering to avoid rationing [16]. At the outset of a merger process, companies are weakly integrated. Since a merger involves integration, the way these firms relate to each other as organisational entities must change. The merger process, including the function of purchasing to support this process, is necessarily emergent. An important aspect of a corporate merger is therefore the fact that it is a learning process. This includes learning the needs and technologies involved in developing a new IS for the new unified company.

The short time frame of the IS development is a major concern when companies choose to merge. Interaction is a continuous process that involves events unfolding over a timeline. This complexity is, following Cantu et al. [25], rooted in that (1) solutions (the outcome of production) can be interpreted differently by different actors in the network, (2) actors usually have dual roles, as resource providers or users, (3) the dual perspectives of actors as resource users and providers are confronted in business relationships through interaction. The development of the new IS system can be considered a complex service, a temporal learning process. Pettigrew [27] proposes a working definition of a process as: "A sequence of individual and collective events, actions and activities unfolding over 
time in a context". In their fundamental nature, processes unfold through synchronised, sequentially interdependent decision-making events in a network interconnected by mutual interactions that develop over time in specific contexts [27-29]. In production, interaction is continuous; tasks continuously unfold and impact interpersonal perceptions. The supply network is therefore never idle since the production operations are dynamic. Change in integration and interdependency is, however, rather slow as it involves different forms of resource investment, the organisational structure functioning as the process context. Figure 1 describes the fundamental approach applied in the study:

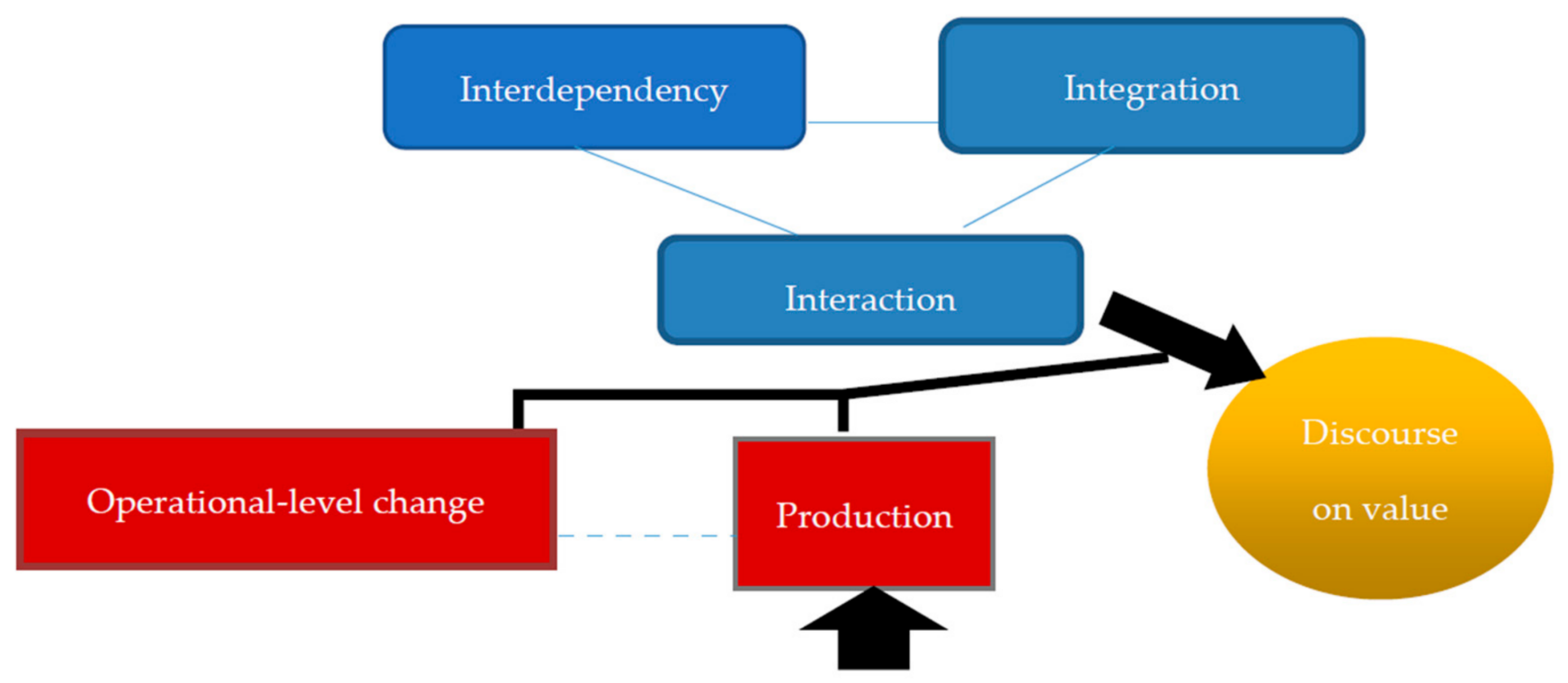

Purchasing function

Figure 1. The conceptual research model.

This conceptual model provides a general understanding of how to picture the supply network in relation to a purchasing event. In this figure, discourse emerges as an outcome of the production experience. Purchase as an operational activity is also a feature of production. It is a supporting managerial activity. The research model depicts networking involving interdependency and integration as fundamental features of a network structure. Within this structure, production supported by purchasing occurs as an interaction in operations. While structural-level development is a long-term strategy since such a change naturally involves investments in capital and human resources, a change in interaction is associated with production understood as a complex process. Since this study is concerned with IS development, "production" encompasses a service, the development of a new IS in the context of the various merging firms and other service providers.

\section{Method}

A single case study strategy was applied since it captures in detail multiple actors' perceptions of varying technology-based challenges, thus providing the required depth and richness that allows the researcher to probe into the "how" and "why" questions [30]. Nine 
interviews with eight informants were conducted. These covered different perspectives of developing an IS in the studied corporate merger context. Table 1 provides an overview of the interviews:

Table 1. List of interviews.

\begin{tabular}{|c|c|c|}
\hline & Informant Role & Interview Topic \\
\hline 1 & Marketing Manager & $\begin{array}{l}\text { Overview of the company and the research issue. } \\
\text { Providing a list of informants }\end{array}$ \\
\hline 2 & General Manager & Overview of the research issue \\
\hline 3 & 2 original IT super-users & Describing their perspective of the merger process \\
\hline 4 & Economic CEO & $\begin{array}{l}\text { The merger from the perspective of the other large } \\
\text { company in the merger process. The perspective of } \\
\text { the person who led the IT development }\end{array}$ \\
\hline 5 & Production Manager facility 1 & The merger process from the production perspective \\
\hline 6 & External IT service provider & $\begin{array}{l}\text { The perspective of the person who carried out the } \\
\text { actual information systems development }\end{array}$ \\
\hline 7 & Production Manager facility 2 & The merger process from the production perspective \\
\hline $8-1$ year after the merger & 2 original IT super-users & The perspective of systems users after the merger \\
\hline $9-1$ year after the merger & $\begin{array}{l}\text { New super user-came from the } \\
\text { other merged company }\end{array}$ & The perspective of systems users after the merger \\
\hline
\end{tabular}

According to Eisenhardt [31], an emergent character of research design is typical of the case study research strategy. Starting with the initial research problem formulation based on hunches, this inductive methodology gradually guides the research towards more specific research issue formulations. Interviews took place mainly shortly after the corporate merger. Interviews started with the CEO of the then-recently merged firm. This interview led to further interviews, following a "snowballing" logic. This logic included abductive reasoning so that each new interview provided new theory-related insights, which again could provide guidance for the following interview as to whom to interview and about what. Other informants included administrative leaders from each of the three merged firms. The various subsequent interviews included IT suppliers and consultants, different users including directors of two production facilities, the manager of the sales and marketing office, and finally, users at the corporate headquarters [12]. Furthermore, a follow-up interview of the "super-user" of the chosen Navision system (the company and IS names are fictitious) was carried out a year after the merger. A concluding meeting with the sales and marketing offices was held a month after this interview to complement the super-user perspective. Saturation was gradually encountered indicating an appropriate point for finalising the research. The merger concentrated on the IS purchasing and implementation of the merged company. This implied a limited need for informants since, in this relatively slim administration, only a handful of people were involved in using this information system.

These semi-structured interviews were conducted in person at the business location of the informant. They all lasted between $20 \mathrm{~min}$ and an hour. Gradually, based on experiences with preceding interviews, interview guides were adopted. Each interview had an adapted set of open-ended questions or topic formulations. Interviewing commenced with the sales and marketing director. He provided an overview of the corporate merger context as well as some other fundamental information regarding the merger and the companies involved in it. He also listed the characteristics of the information system needs and technicalities. These interviews were taped and transcribed. Following the well-known "snowballing" principle, interviews were conducted until concluding that a potential next informant could not be expected to provide substantial insights into the researched issue. Interviews were conducted to describe both the current standing of the IS development and previous events. 
This use of informant memory is associated with recall bias. To counter this, different informants were interviewed on the same topics to provide variation in the perspective on the same issues.

Data were analysed based on the literature review providing the frame of reference provided in Section 2 of this article. While the provided case narrative offers a narrative of interactions following a timeline, analysis follows the frame of reference. This conceptually driven form of analyses [32] means that the three chosen concepts, "interaction", "integration" and "interdependency", derived from the article by Janusz et al. [15], are discussed in relation to practices found in the case narrative. This provides a particular approach to understanding the structure of the IS development project, why particular actors interact, and how they interact. In conclusion, this helps answer the overall research topic of this study, which concerns better understanding of the more detailed nature of networking in this merger context. Alm et al. [12] presented the following case text in a shorter form. Here, it is expanded and rewritten to fit the above-discussed analytical needs in the frame of reference of this paper.

\section{ICT and the Corporate Merger Case}

\subsection{Background for and Foundation of the Merger}

The decision to merge was the outcome of four to five years of interactions among five companies that saw the complementary advantages of being potential members of a new unified firm. The figure below shows the network of large and small firms involved in the merger in the Norwegian seafood industry:

Two large companies (A, B) and three small companies (C, D, E) were involved in the corporate merger process. While the two largest companies, A and B, were already internally integrated through functions such as raw material purchasing, production, logistics and sales functions, the smaller companies were simply producers. These companies, therefore, were also mainly sub-suppliers to other firms that carried out other functions, importantly, sales and marketing. The headquarters of one of the larger companies involved in the merger (A) became the administrative headquarters of the merged company, while the purchasing and sales functions were located in the former headquarters of the other larger company (B). Thus, the two large companies became the lead players in the newly merged company.

All the merged companies purchased the same type of seafood raw material, industrially processed the product heading for the marketplace and packed it for freezing. At the time of the merger, the merged company had nine comparable production facilities located along the coast of Norway. They all produced pelagic seafood products. However, one facility also specialised in further processing of the raw material. Figure 2 provides an overview of the studied IS development as process in the context of merger.

The business culture at the two main merging companies (A and B) was quite different at the time of the merger. One of the companies (A) was described as having a strictly formalised command system to support production and distribution. The other large company (B) involved in the merger strived to create a flatter organisational structure. In this company (B), managers either shared office space with the employees or regularly mingled with them, for instance, in their three production facilities. The three small business units (C, D and E) were mainly production oriented. These smaller companies had small administrations consisting of a few people who easily and informally mingled with a low degree of formalisation. One of the small companies (C) had a relatively advanced system to manage production and logistics at its facility. The other small companies (D and E) involved in the merger process had simple ISs facilitating predominantly manual production and logistics management. 


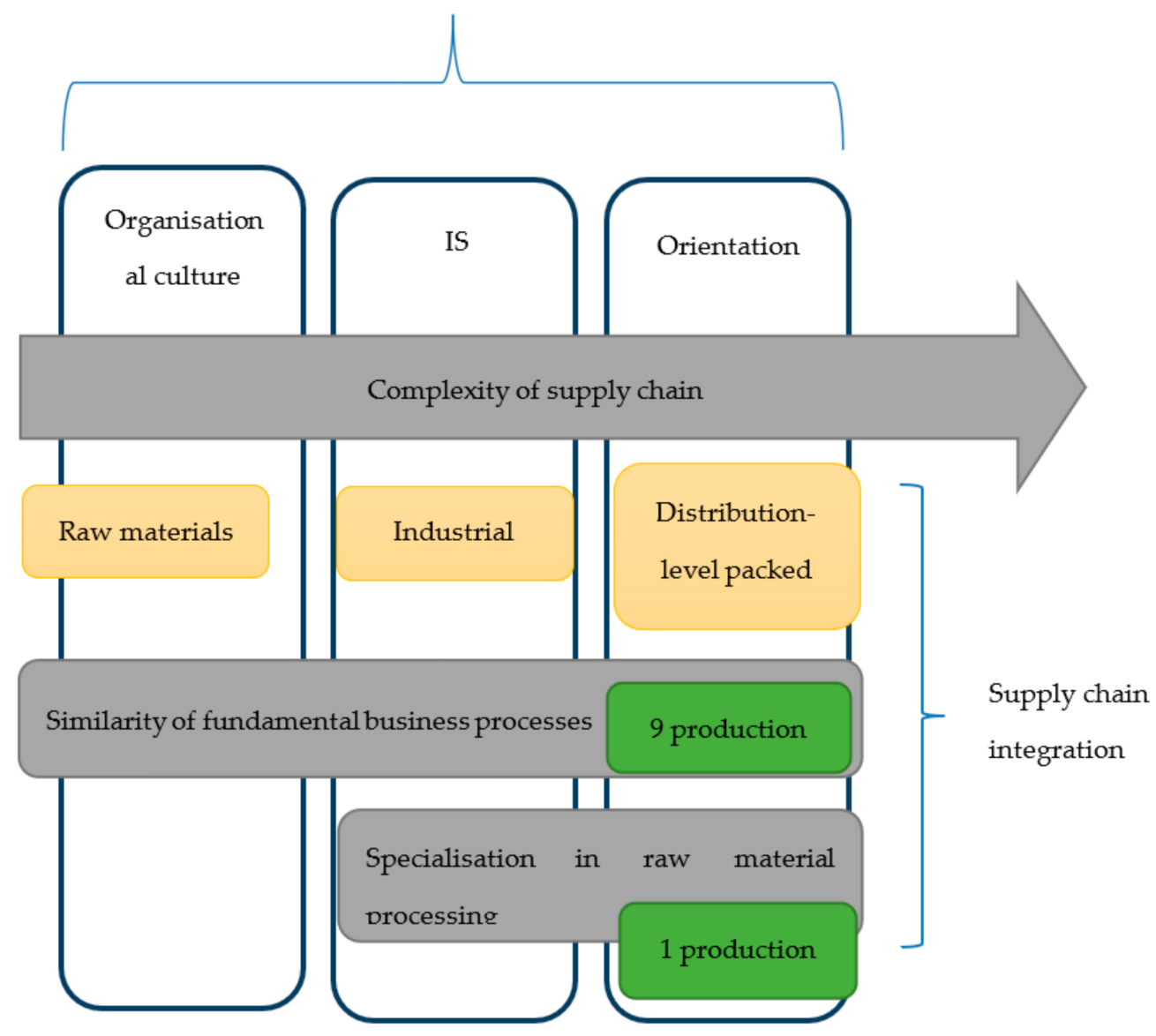

Figure 2. IS development through the merger process.

In the later 1900s, one of the larger companies (B) (the one with the flat organisational structure) acquired a Danish-developed ERP system from a lesser-known supplier named Guide. Guide was at this time a DOS-based system involving a rather complicated use of computer function keys. This system had been updated and, at the time of the merger, was Windows-based, eliminating the previous need to use function keys. The choice of Guide at this company (B) was rather coincidental. Demand specifications were sent by fax to 17-18 companies that were believed to be potential suppliers of the desired IS. When faxing the standardised offer, the secretary misinterpreted one of the recipients on the list. The fax was instead sent to a company with a very similar name to that on the list. This company was an agent for the Danish Guide system that eventually won the contract and the company (B) ended up using the Guide ERP system which was in use until the merger in 2007. Throughout their history, this Norwegian seafood producer (B) has been their only customer in the Norwegian seafood industry.

The other large company $(\mathrm{A})$ involved in the corporate merger (the one with a more rigid hierarchical organisational structure) used another ERP system developed by Microsoft. Navision system is a Windows-based ERP system. From the managerial perspective, IS purchase and development was regarded as an administrative task. The users were only involved in its acquisition and development to a limited degree. Just as in the case of Guide, the Navision ERP system was also being gradually improved. Functionally speaking, this system was comparable to Guide. Navision, however, proved better in generating economic reports to monitor profitability. In addition, since its installation, Guide had not undergone any upgrades at company B. Sales personnel at the company (B) using the Guide system had become accustomed to selling products using mainly paper printouts, while this practice had long become obsolete at the other company (A). At the time of the merger, an agent was responsible for supplying the Navision system (later 
referred to as Actor 5). This company had once been a relatively large company with many employees in Norway, mainly system programmers. However, by the time of the merger, this had radically changed. By then all of the employees had been laid off and all system development functions had been outsourced to Mauritius with only the manager as a contact person, IS designer and intermediary with programmers.

\subsection{System Choice}

Choosing the ERP system initiated a complex development process that also created a purchase need. The representatives of the two larger companies (A and B) advocated their systems-Guide or Navision. Through this selection process, the organisations agreed on limiting changes in the design of the IS as much as possible. Guide had a few awkward technicalities, such as horizontal document printouts, making placement in envelopes with see-through plastic address frames difficult. Navision was, on the other hand, part of a globalised IT software corporation. It was therefore perceived as a more secure investment than the more obscure Guide. Guide could, however, document that their product scored high in independent tests. At the time of initiating the merger process, both companies offered comparable module-based systems. Such systems apply standardised IT components that are easily adapted to user needs with limited alterations. Both firms stated they would provide their customers with prototype systems. This meant that more detailed system applications adapted to user needs could be tested.

The human side of this process was clearly visible. One informant stated that "no-one was completely neutral in this process". Meetings were initially held throughout the winter and early spring, and the merger was carried out in June of that year. Only two managers from each of the two larger companies (A and B) directly involved in the merger process took part in these meetings. The company (B) using Guide invited their previous IS manager, who was deeply involved in the selection, implementation and development of the Guide system at one of the large companies (B), to advocate for selecting the updated version of the Guide system in the merged company. During the process, the financial manager (further referred to as Actor 1) from the company (B) using the Guide system was given complete responsibility for choosing between Guide and Navision. The exact reason why this person (Actor 1) was given the responsibility to make this choice was never expressly stated. However, when comparing the two systems, this manager perceived Navision as superior in terms of accounting and calculation functionality. This manager (Actor 1) later offered to move his workplace to the corporate headquarters of the merged company (at the location of the previous company A). However, he still lived in the same town as the company (B), which used the Guide system. This was the location of the sales and marketing department. He chose this location since his family lived there. By May 12 in the year of the merger, Actor 1 made an autonomous decision to award the contract to the supplier of the Navision ERP system.

\subsection{Design and Implementation}

Limited time was the main obstacle in the IS development in this case. From contracting in mid-May, the system was supposed to be up and running by the beginning of July. The merger was to occur on the first of June of that year. The time of the merger coincided with a low production season in the industry. The short time meant that it was impossible to deliver a fully operational ERP system by this deadline. It was decided to prioritise the sales and marketing department's information needs. This location was using the Guide system before. Production would be resumed using the existent IS at each seafood processing plant. These would systematically be replaced by Navision and then connected with each other. The manager (Actor 1) who had chosen the Navision system had the main responsibility, on behalf of the merged company, to develop the new Navision ERP system. This person (Actor 1) worked alongside two other key personnel members: the logistics manager (Actor 2) and the financial manager (Actor 3) at the sales and marketing 
office. They put in long working hours during the six weeks when the fundamental IS development was carried out.

Process specifications were set by users of screen menus making sketches for the IS developer (Actor 4). The merged company hired a person from the IS developer previously used by the firm (A) which originally used the Navision system. This person (Actor 4) then handled communication between the merged company and the Norwegian Navision agent (Actor 5). Actor 5 functioned as an intermediary between the IS developer (Actor 4) and the programmers in Asia (group of Actors 6) to which this firm had outsourced its activates. Actor 4 communicated regularly with future users (group of Actors 7) on how to design vital features of the IS in the merged company. These users were mainly associated with purchasing and selling. By the beginning of July, the new system featuring these functionalities was running at the sales and marketing department. This department also handled purchasing through the Norwegian pelagic seafood sales monopoly's electronic auctioning system. This was a provisional solution only for sales, purchasing and marketing. Inventory and shipment control were at this initial stage rendering manual processes.

\subsection{Initial Use in the First-Year Period}

A total of 14 persons (group of Actors 7) working in the sales and marketing department at the merged company took part in the IS development project. Sales personnel sat at a private desk with a computer terminal in an open-space office. The sales and marketing manager (Actor 8) also sat an open-space office. Development involved active learning through interaction among sales personnel from both the larger companies (A and B) and the three new personnel members hired externally. They constituted the newly formed department.

After using the system for three months, the personnel stated it was well adapted to their needs. The IS developer (Actor 4) was said to have done a good job. The sales and marketing manager (Actor 8) used to be at the previous Guide-using organisation (company B). He pointed out that developing the Navision system had taken less than three months involving mainly personnel from company (A) that had previously also used the Navision system. He continued to point out how implementing the Guide system, which had been perceived as successful, had taken six months, involving a higher degree of user involvement, with frequent interactions with the Guide supplier.

The training of personnel to use the new Navision system was carried out simultaneously by following continuous development and adaptations. The sales and marketing manager (Actor 8) expressed that “ ... in the beginning, I saw a great deal of frustration with the new system. None of the personnel, regardless of the original organisation (company A), knew how to work with the system at first. Of course, when a system is new, there are many errors. You need to make corrections on an ongoing basis". The people at the sales and marketing department (that also carried out purchasing pelagic seafood raw material) were not surprised that the two initial months after the merger posed many challenges. Solutions during this first period of the Navision IS use involved plenty of ad-hoc problem-solving by the IS users (group of Actors 7). When describing this period of initial use, the marketing manager of the merged company (Actor 8) said that "... we took hold of the person responsible at the headquarters, and he travelled back and forth. Everybody was allowed to express their deep thoughts about the IS development. Some were angry, others were happy". A person was chosen to be the "super-user" (Actor 9) of the system. She kept track of Navision and had two capable persons (Actor 10 and Actor 1) working under her command.

The sales and marketing office was structured into teams, with one of the personnel members being more proficient in Navision than the others. This represented " ... a contact for minor problems". These persons (Actor 10 or Actor 11) registered and noted down minor problems that were communicated through the super-user (Actor 9). The super-user was the link to the IS developer (Actor 4) that continued to service the Navision system on a daily basis. This super-user was chosen by the top management. She was 
employed after the merger, so she represented an alternative and new perspective in the organisation. The super-user's function was to limit the number of contact points and communications between the management service firm (Actor 4), responsible for running and development of the Navision system, and the users at the sales and marketing department (group of Actors 7). The sales and marketing personnel had to learn to carry out the same functions-purchasing, selling and coordinating logistics-in a new manner.

Implementation of the new IS reduced the need to use fax communications. Nevertheless, the personnel at the sales and marketing department (group of Actors 7) pointed out that they felt the need to better link their function to the 10 production facilities that were manually linked with the Navision system. In addition, the previous Guide system supported the use of barcode scanning at the production facilities linked with Guide, reducing the number of discrepancies in transport to customers. At the initial stage, this functionality was not yet implemented.

\subsection{IS in Use a Year Later}

After one year, the sales and marketing office members still considered themselves employees of the preceding Guide-using organisation (company B). This identity did not disappear. The externally hired super-user of Navision (Actor 9) had to negotiate her way into the well-integrated organisation at the sales and marketing office. The structural design of the Navision system support system remained unchanged with the IS developer (Actor 4) supporting IS functioning at an operational level, including minor program adaptations and more complex tasks sent for programming through the Navision agent (Actor 5). Throughout the years, the system was gradually improved through a trial-and-error process. Over time, Navision has proved to provide what the users call "good" support for their sales activities. For instance, four product certificates are now automatically generated by Navision, reducing errors and time necessary to create these documents. In addition, as the users pointed out, this creation of documents still requires further improvements.

The super-user (Actor 9) at the sales and marketing office was the first to have direct contact with the IS development firm (Actor 4). This contact was decided later to go through a manager at the sales and marketing office functioning as an intermediary collecting information from the users (group of Actors 7) on problems with using the Navision IS. This person then creates lists of issues to be solved and sends them to the IS developer (actor 4). The super-user (Actor 9) expressed that the reason for this change was that she became too outspoken in her job, coming up with possibly too many suggestions regarding the required improvements to the Navision system. At this time, the super-user (Actor 9), however, still believed the representative of the Navision supplier was communicating well with the users (group of Actors 7) when they implemented the Navision system at the beginning. She (Actor 9) now is not allowed to email this IS developer (actor 4). Change in the Navision IS is slow since the Navision supplier, which had outsourced its programming resources, encountered problems in delivering programming services. During this first year of use, all their programmers (group of Actors 6), originally located in Mauritius, collectively resigned at once giving the IS developer a huge challenge to find new programmers. This took some time, and, eventually, a group of programmers in India was hired with initial communication problems. The super-user (Actor 9) also expresses frustration regarding Navision change suggestions being communicated through at least four stages. She asks, "How can this information not become distorted?" In addition, the super-user (Actor 9) feels satisfied that Navision users (group of Actors 7) are comfortable now with the use of the current system. The previous super-user of the Guide system states that " ... we never had those problems with Guide!" The adaptations were made as part of the overall system delivery. The users (group of Actors 7) also mention that the improvements aim to make the Navision system function in accordance with the contract with the Navision supplier. 
Two years after the merger, Navision still covers only a part of the merged company's information needs, primarily sales and distribution. In addition, production and logistics are still supported by ISs interlinked by manual communication modes-fax or email attachments. Expanding ERP use to product and logistics is under discussion. There is, however, a feeling in the corporate headquarters that further IS development should be limited as much as possible. IS is regarded as an expense. Development of the Navision system is limited to corporate fundamental needs. Sales and marketing department representatives (group of Actors 7) point, especially, to the discrepancies in goods delivered and goods received as a continuous and unsolved problem. Figure 3 provides an overview of the studied IS development in stages:

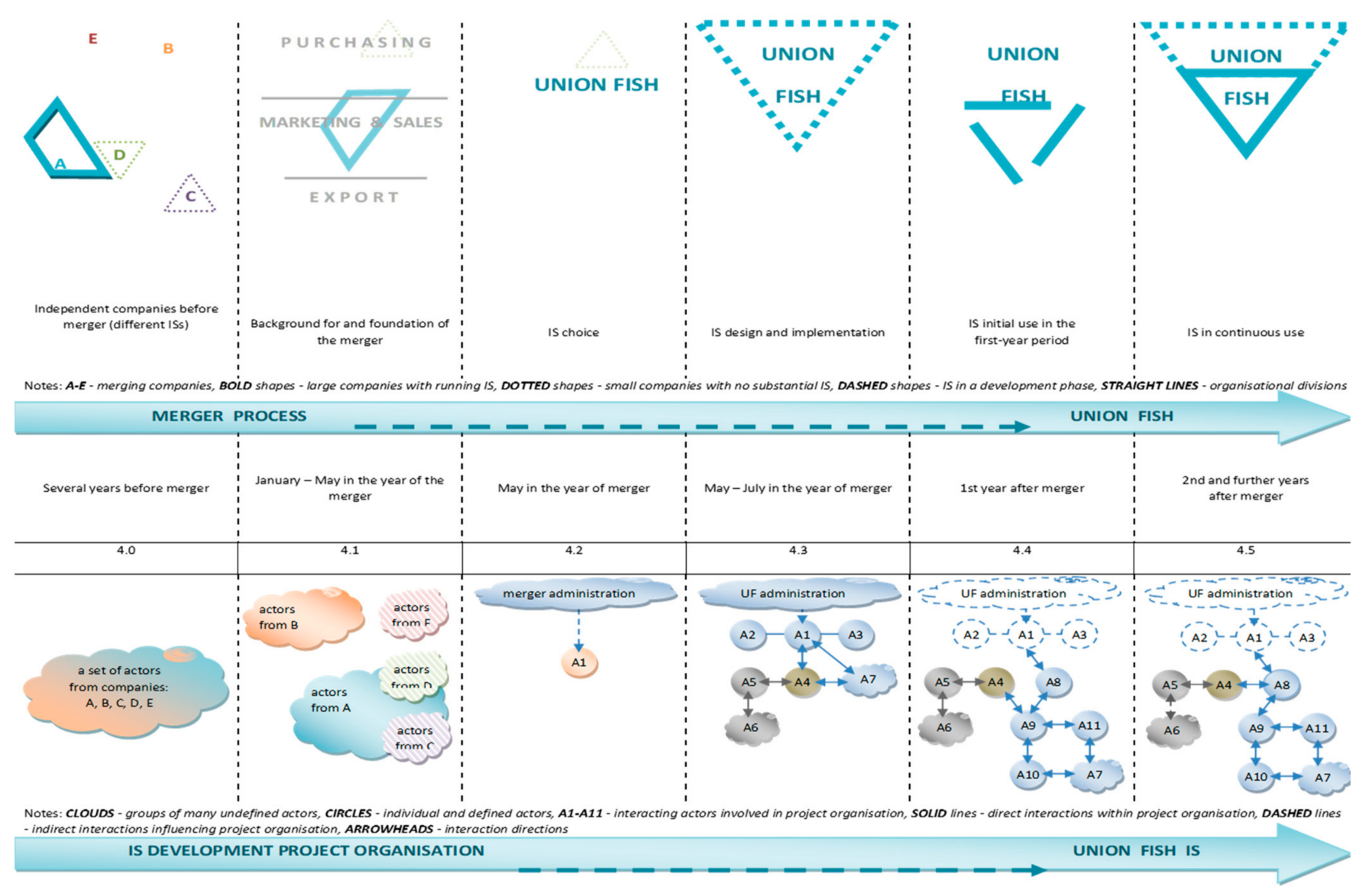

Figure 3. IS development in the merged seafood production firm.

The figure describes the timeline of how first the fundamental issues need to be negotiated and decided upon. At first, although fundamental and important, they are relatively simple. Complexity increases through the perception of increasing detail of issues requiring solutions. Figure 3 shows the timeline arrow of how these issues become organised through networking. At the intermediary stage, mainly the months before the merger, IS development leadership is strong and rather coercive. This coerciveness weakens as the actors in the IS development process gradually start to use the system. Appendices A and B provide a detailed description of the stages in IS development described in this case study.

\section{Analysis}

The analysis follows the structure of the frame of reference. This implies first, considering interdependencies, then, integration and finally, how integration takes place in the context characterised by features of interdependency and integration. Since the case 
narrative follows a timeline, analysis will importantly include a change in these factors through the IS development project (see Appendices A and B).

\subsection{Interdependency}

The first focus is on why actors in the case do actually interact. The case study is associated with what may be termed as "horizontal integration": the merger of more or less similar competing firms (five companies: A to E). Resources of the merging firms are comparable. The merging companies are at the same level of production and process the same type of seafood product in similar manners. The main difference is the size of the companies. This is especially evident in the case of administrative functions carried out by the companies before the merger process, including the state of IT use in different companies. The case study consists of two groups of companies:

1. The two larger companies (A and B).

2. The three smaller strictly production-focused companies (C, D and E).

In the narrative, we see that the main revealed and active interdependency is the interaction between the two larger merging companies (A and B). The smaller companies (C, D and E) remain largely passive in the development process. The merging companies represent a network in which the only active relationship is between the two larger companies (A and B). The other relationships function to inform the smaller companies (C, D and E). The choice of the Guide or Navision system as the foundation for the new IS was the cause of the principal friction.

In this setting, the main aspect of interdependency is the power found in one focal business relationship. This dyadic core, the relationship between the two larger companies (A and B) involved in the merger, expands to encompass external IS providers, as these actors become increasingly involved in the IS development. Through the merger, interdependency becomes increasingly centralised within this small network, with the external consultant playing a leading coordinating role. When the firms merged, this consultant somewhat withdrew from the network to become a supporting agent rather than a central one. When the firm merged, it became a single unit integrated on paper.

An overall finding is that interdependency in purchasing behaviour is dynamic, albeit changing at a slower pace than the production of the IS representing the service production process. This project organisation had a limited period time frame where the development work needed to get done quickly, the speed of interdependency change was fast, most likely faster than in scenarios of continuous production operations. This velocity of interdependency change, however, needs to be more closely investigated to ensure proper comparative analysis. This implies that the structure of the IS development interaction is contingent on its organisational context.

\subsection{Integration}

Integration means highlighting features of the network structure. This concerns the changing strength of temporal project network ties. This temporal development process is, as discussed in the frame of reference, regarded as production. The production takes place in the context of the network of merging firms. The integrating network of purchasing to support the IS development project is associated mainly with the focal business relationship between the two largest merging companies (A and $\mathrm{B}$ ). This picture is broadened as the IS purchasing is expanded to encompass external IS service and system providers. Then, the integration also encompasses these actors. In the case study, the management issue of integration in the IS development does not include the smaller companies (C, D and E). Given their state of dependency on the rest of the network and their lack of power, they are forced into submission. This reflects how integration is dependent on features of interdependency in the network structure.

The purchasing of the IS development, a service acquisition, was organised in a coercive mode. The corporate leadership of the newly merged firm chose to outsource the IS development. It had to trust in the hired IT consultant's knowledge of both the 
logistics and sales functions the IS was to support, and IT. Given the short time frame, this also had implications as to how the new IS was technically designed and implemented. Likewise, as interdependency is dynamic, the case narrative shows how integration is a flexible feature of the project network involved in this purchasing behaviour. Actors do business with other actors to whom they are related by interdependencies, and this is characterised by integration. Integration varies, it increases and decreases the various actor bonds in business relationships involved in this IT purchase. In the short-lived project, the organisation of the studied IS purchase and development project, as well as investments through purchase to support further integration, is limited. Furthermore, the velocity of development implies that features of integration need to be flexible. IS development is a time-restricted, limited integration effort. This is a provisional organisational structure with a provisional form of integration. This is especially clear when noticing how the project network mainly involved people doing this on a part-time basis. This means that integration is clearly impacted by variation in the project context and the actor bonds of immediate networked actors. This is a loosely coupled, time-limited purchasing endeavour.

\subsection{Interaction}

This section focuses on how purchasing supports the actual production of the new IS through an inter-actor collective effort embedded in the development project network as a process. The case reveals how purchased IT-based solutions descriptively follow a timeline. Following the variation accounted for on the timeline is essential to describe this time-limited process. They are in part sequentially interdependent, each solution being created, following Thompson [16], through the use of intense technology involving mutual adjustments among the firms. IT-based IS development is a process, but this process is associated with uncertainty due mainly to mutual adjustments. In the case study, since two of the firms (A and B) are larger and have greater IT experience and more developed IS resources, the use of intensive technology, seen through their mutual adjustment, took place almost completely in the two firms which previously used the Guide and Navision systems. This reveals the role of power associated with the firm size as well as IT competence. This IS development follows a sequentially interdependent timeline that can be described as an interactive learning process. It is complex. This process is fundamentally reciprocally interdependent. In line with Thompson [16], cases of reciprocal interdependency, this form of interdependency being quintessential to production, are complemented by sequential and pooled interdependencies.

In accordance with Stabell and Fjeldstad [26], purchasing to support IS development may be characterised as a value shop. Variation is a key feature of such production. In this "shop"- -the project organisation of the IS development in this corporate merger-the actors interact, share fears and frustrations and some offer solutions. This shop became, however, quite coercive once the Navision system was chosen over the Guide system. The project leader (Actor 1) was then given powers to override discussions within the IS development process. The consequence of this procedure was that the IS system of the newly merged firm did succeed in creating a rudimentary barebone design for use. It was barely adequately operational the day the merger was initiated. This IS was, however, a provisional solution, a foundation for further IS development. When time became more abundant after the merger was complete, the IS became subject to incremental development. It was gradually developed through a procedure that may be interpreted as both "repair" and "investment". This aftermath of the IS development took place at a slower pace and was modified to better involve the voice of the IS users (group of Actors 7). Purchasing normally aims to secure the value-in-use norm. This case narrative, therefore, indicates that however important value-in-use is as a quality factor, it may be simply impossible to apply when time is limited. Dialectic, usually mainly manual, interactions in cases of reciprocal interdependencies are time-consuming mutual adjustments. They consume people's time and are costly coordination procedures. The purchase benefit is securing an IS value-in-use objective. The mutual adjustments were overruled in this case by limiting 
input from the IS users to almost nil. This compromise limiting IS user involvement was improved after the merger. Over time, the merged company did get quite a good IS, but not without organisational challenges underway, largely due to limited user involvement. This organisational structure of the IS development project is depicted in Figure 4.

\section{Dynamics of interdependency an integration influenced by and supporting interaction}

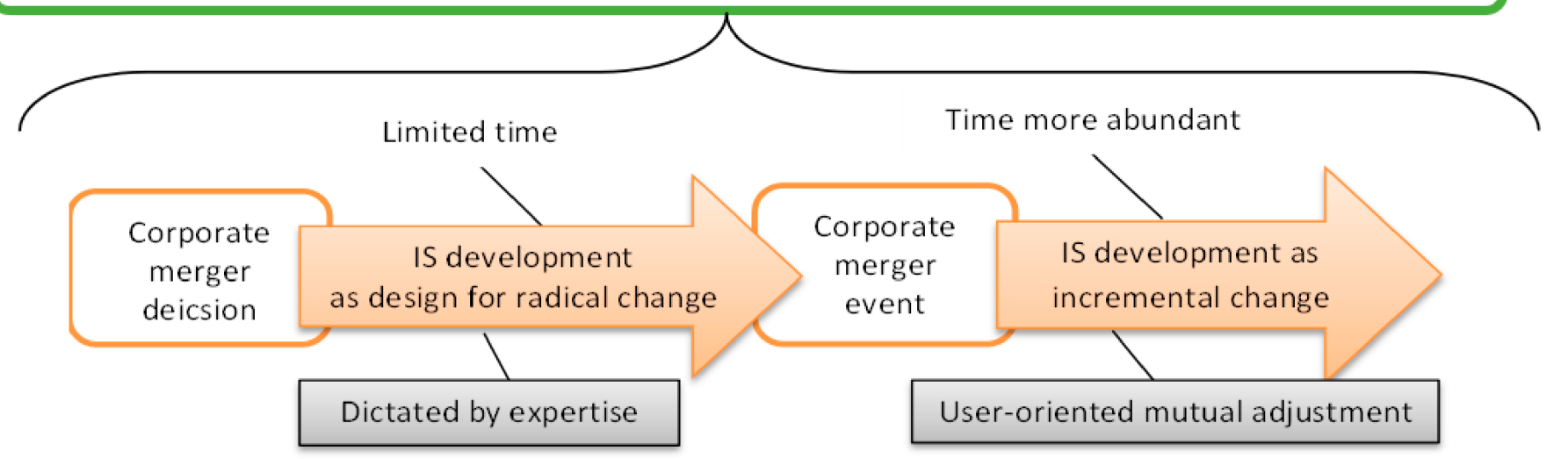

Figure 4. The IS development in different, time-determined logic of corporate merger.

Figure 4 illustrates how interaction is impacted by its transforming context. This change is characterised as features of the organisational structure consisting of dynamic integration and dynamic interdependency. In the developed framework, we further elaborate on interdependency whose structure is also characterised by integration. The causality between the structure (characterised by interdependency and integration) and production process of the IS (characterised as interaction) is bidirectional.

\subsection{Discourses and Interaction}

This study exemplified five major discourses associated with the studied information system development: (1) "time", (2) "product information accuracy", (3) "information and communication systems and belonging", (4) "handling unruly business processes" and (5) "economic constraints" [12] (pp. 378-379). These five discourses point out actual topics of interaction, interpretation, conflict, negotiation and learning in this corporate merger context. Findings of the paper were articulated as: "The levels of professionalism observed in software engineering are generally lower than those in other branches of engineering, although there are exceptions. Senior managers are often ill-qualified to handle issues relating to complex IT projects. The importance of project management is not well understood and usually underrated. The vital role of the system architects in major IT projects is frequently not appreciated and there is a shortage of appropriately skilled individuals. Basic research into complexity and associated issues is required to enable the effective development of complex, globally distributed systems" [12] (p. 269). The analysis also reveals that IS development was different before and after the actual merger. This is due to the change in the context. After the merger, the provisional IS was working and limiting the pressure to develop. Likewise, there was no longer a clear deadline regarding completion. These factors had an impact on process velocity. This also underpins the contingent nature of the studied IS development project. In our study, this adjustment is faster due to the speed needed to finalise purchasing in the project. The purchasing process supporting the production of the new IS is highly emergent. To sum up, the study reveals that IS development is a complex process. The reasoning for this is embedded in the intricate workings of this project network. There is no clear causality as to why the IS development follows the path it has. Given the magnitude of the objective, to create a new working IS in a relatively short time frame, the organisational solution is to muddle through 
and use trial-and-error as the approach to development. The research does not indicate that this is entirely wrong. This is in part because the economy of mutual adjustment is complex and cannot be predetermined. Mutual adjustment is carried out by interaction, and, in the studied case, this was only weakly planned at a relatively short-term level.

\section{Conclusions}

The case narrative describes a scenario of actors interactively muddling through to reach a solution. The discourses pointed out by Alm et al. [12] are the key reason for the characteristics of interaction. These discourses provide human reasoning for how purchasing solutions to support IS are found. The purchasing process is therefore highly emergent and quite frenzied. Planning has almost no impact on this process. This is largely due to the discourse on "time" coupled with "handling unruly business processes". A culture of purchase and development is set in this project organisation. The choice of development procedure, however, creates a barebone IS solution, which is a foundation for further development. Development process emergence is continuous; there is no real project time borderline. When time is short as in this project, interaction is not dependent on the quality of the relationship. Criticality seemingly pushes forward a need for interaction regardless of organisational atmosphere. Resources are pooled and managed coercively. The result is hardly an optimal IS. Given that the developed IS is a barebone solution, it may be turned into a good workable IS over time.

Loose coupling and weak integration are hence important features of the structure of the studied network. This facilitates flexibility so that different resources (including actors) may be switched and recoupled as needed over the project timeline. In cases of mergers, integration is developed to encompass collaboration in the project organisation form and subsystems supporting everyday incremental supply chain development. This also implies expanding SCM to coordinate the working of subsystems as well as the interface between these time-limited merger-related subsystems as functional entities. Their aim is to support the everyday operations in the supply chain to which the production company belongs.

Planning has some impact, although more as a human mindset rather than detailed numerical calculations. In the case study, the merged companies sought the simplest way to purchase and thereby develop their IS into the new unified corporate entity. In this subsystem of development, given high uncertainty and reciprocal interdependency, the quality of collaboration is a critical feature. Mutual adjustment is therefore expected since the core feature of the described IT purchase and development project is process variation. Reciprocal interdependency involved interaction in a well-developed business relationship exemplified by integration and trust. However, due to time limitations, coercive dictation overrules reciprocal interaction administered by the external IS developer.

Since time is an important constraint in this form of project organisation, we can also note the importance of contingencies when planning the IS development. The discourses are features of this contingency. The short time frame impacts interdependency in the project network, simplifying it to a core business relationship, later to include external professional IT agents. This view implies that purchasing in such project contexts should view variation as a form of normality and not something to reduce. Planning is associated with developing the process context to handle the need for the management of this form of the development process as an emergent phenomenon.

An economic and effective merger process considers purchasing associated with developing IS value-in-use an overall objective. Economic reasoning is also one of the discourses revealed by Alm et al. [12]. The case study reveals that this aim may be problematic when adopting a short-term perspective. IS users as customers seek value. This value is, however, complex and cloaked in uncertainty. The final IS design is created through a very limited degree of interaction. This design is therefore hardly optimal, but subject to incremental change once it is put into use. A picture of purchasing to support IS development as a top-down led output of deterministic managerial planning is flawed. It 
is rather an incrementally complex design. What is highlighted is the quality of interaction rather than the quality of plans. Interaction takes place among networked actors.

The importance of networking for developing cases of technological and organisational uncertainty implies the need for user involvement. This involvement is limited through the initial brief development stage, and decisions are implemented with limited user participation. Interaction, in this case, is complex and weakly aligned with economic objectives. To what degree this is "wrong" remains unclear. How is it possible to economically cope with this messy reality of resource development in weakly integrated networks? Should planning tools be further developed? Alternatively, should networked actors learn to better produce service in the context of uncertainty? These questions point to paths for further research, including various processes involved in corporate mergers. Purchasing is, accordingly, revealed as cloaked in intertwined and continuously changing networked relationships. This obscurity means that, in this case, purchasing was a highly complex undertaking, never following a neatly planned set-up.

Future studies may also consider purchasing associated with the IS development in corporate mergers within other types of industry, including cases of vertical integration. Is the IS development in cases of corporate mergers aimed to develop vertical integration a more harmonious process since these companies are complementary in their market relationships with each other? Furthermore, a qualitative survey of firms that have undergone corporate mergers may reveal industry-wide perceptions of what the main challenges of mergers in firm integration are, including, how the IS development is perceived in such a context. In addition, a quantitative survey of experiences from companies that have developed new ISs in the context of corporate mergers would be beneficial in providing generalised data on the subject. Regarding the IS development, more focused approaches may apply the Open Group Architecture Framework (TOGAF) [33] or the European Interoperability Framework [34].

Author Contributions: Conceptualisation, P.E., A.S., A.J., F.A.; methodology, P.E., A.J.; formal analysis, P.E., A.J.; investigation, P.E.; writing—original draft preparation, P.E., A.S., A.J., F.A.; writing—review and editing, P.E., A.S., A.J., F.A.; visualisation, P.E., A.J.; supervision, P.E.; project administration, P.E. All authors have read and agreed to the published version of the manuscript.

Funding: This research received no external funding.

Institutional Review Board Statement: Not applicable.

Informed Consent Statement: Informed consent was obtained from all subjects involved in the study.

Data Availability Statement: Not applicable.

Acknowledgments: We especially would like to thank Anniken Karlsen of NTNU and Kristian Alm of Norwegian School of Management BI for their help in the data collection and the preliminary analysis this paper builds upon. Anniken took part in all the interviews during her time as a $\mathrm{PhD}$ student at the University of Bergen, and her inspiring help made this work especially rewarding for us all. Kristian helped with developing the ethics aspect of this study, including introducing us to discourse analysis.

Conflicts of Interest: The authors declare no conflict of interest. 


\section{Appendix A}

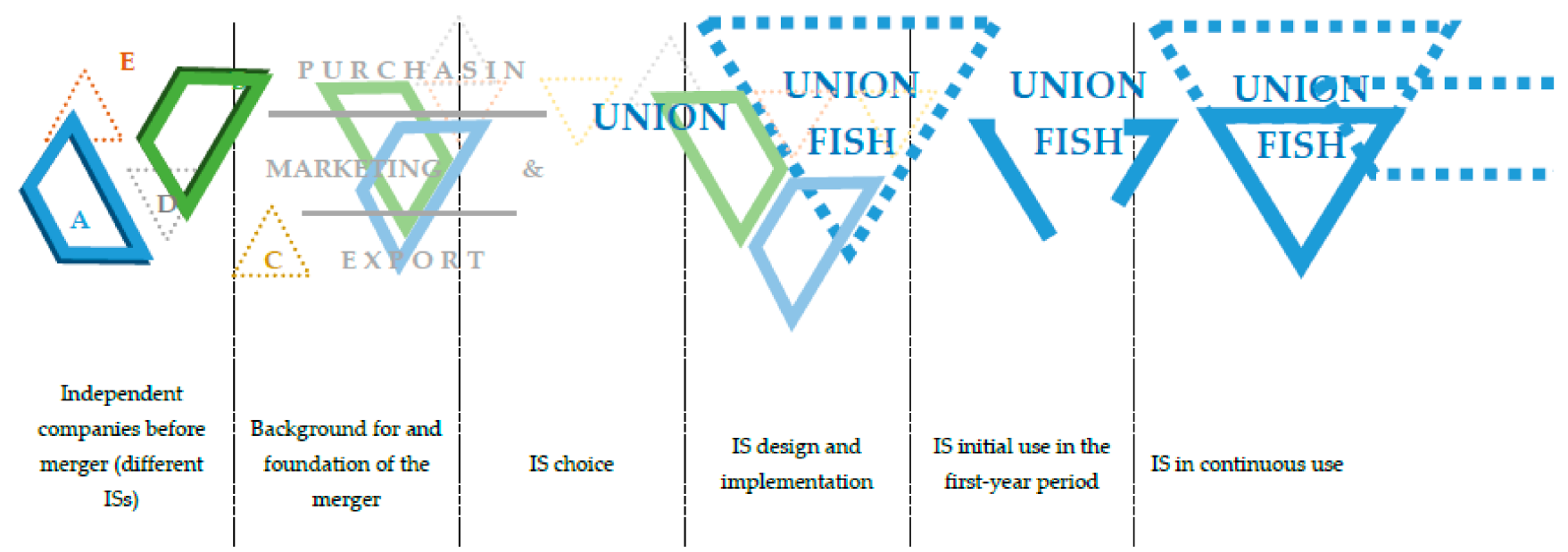

Notes: A-E-merging companies, BOLD shapes-large companies with runing IS, DOTTED shapes-small companies with no substantial IS,

DASHED shapes-IS in a dewelopment phase, STRAIGHT LINES-organisational divisions

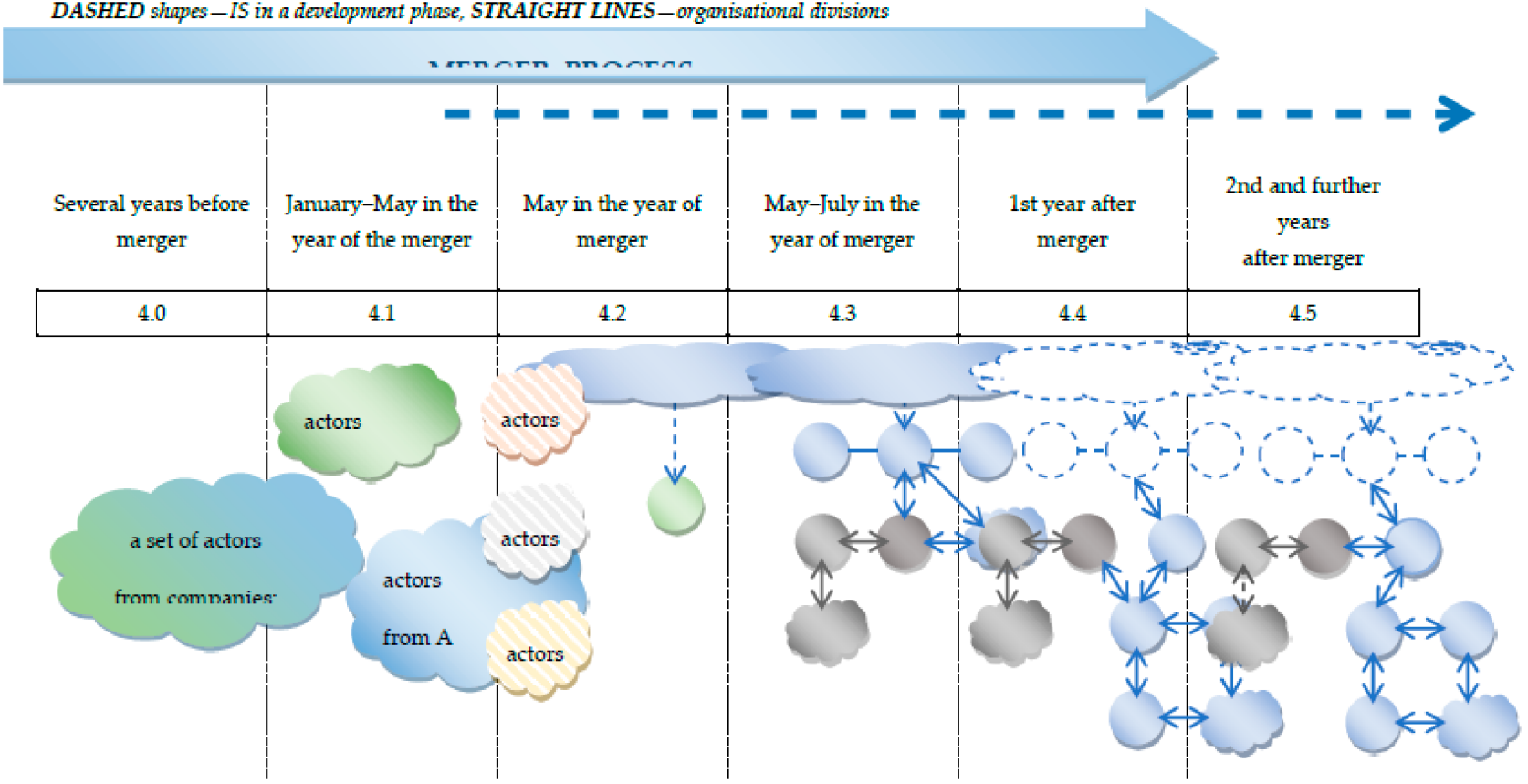

Notes: CLOUDS-groups of many undefined actors, CIRCLES-individual and defined actors, A1-A11-interacting actors inwolved in project organisation, SOLID lines-direct interactions within project organisation, DASHED lines-indirect interactions influencing project organisation, ARROWHEADS-interaction directions

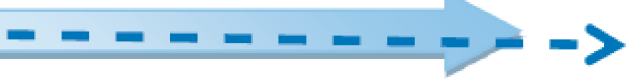




\section{Appendix B}

\begin{tabular}{|c|c|c|c|c|c|c|}
\hline Timeline & $\begin{array}{l}\text { Several Years } \\
\text { before Merger }\end{array}$ & $\begin{array}{c}\text { January-May in } \\
\text { the Year of } \\
\text { the Merger }\end{array}$ & $\begin{array}{l}\text { May in the Year } \\
\text { of Merger }\end{array}$ & $\begin{array}{l}\text { May-July in the } \\
\text { Year of Merger }\end{array}$ & $\begin{array}{c}\text { 1st Year } \\
\text { after Merger }\end{array}$ & $\begin{array}{c}\text { 2nd and Further } \\
\text { Years } \\
\text { after Merger }\end{array}$ \\
\hline $\begin{array}{l}\text { IS development } \\
\text { project phase }\end{array}$ & 4.0 & 4.1 & 4.2 & 4.3 & 4.4 & 4.5 \\
\hline $\begin{array}{l}\text { Interdependency } \\
\text { (reasons for } \\
\text { and/or results } \\
\text { of interactions) }\end{array}$ & $\begin{array}{l}\text { All companies } \\
\text { purchasing the } \\
\text { same type of raw } \\
\text { material and } \\
\text { transforming it } \\
\text { into } \\
\text { distribution-level } \\
\text { packed goods. } \\
\text { Different business } \\
\text { cultures. } \\
\text { Similarities in } \\
\text { market } \\
\text { orientation. }\end{array}$ & $\begin{array}{l}\text { The need for one, } \\
\text { unified IS for the } \\
\text { upcoming } \\
\text { merged } \\
\text { corporation, } \\
\text { instead of } 5 \\
\text { different ISs. }\end{array}$ & $\begin{array}{l}\text { Sourcing for a } \\
\text { new IS and its } \\
\text { supplier. } \\
\text { Limiting change } \\
\text { in the } \\
\text { administrative } \\
\text { process and the } \\
\text { need to learn a } \\
\text { completely } \\
\text { new IS. }\end{array}$ & $\begin{array}{l}\text { The initiation of } \\
\text { IS development: } \\
\text { Union Fish } \\
\text { process } \\
\text { specifications and } \\
\text { sketches of screen } \\
\text { menus sent to the } \\
\text { IS developer. }\end{array}$ & $\begin{array}{l}\text { The simultaneous } \\
\text { UF users' training } \\
\text { in the use of the } \\
\text { new IS along with } \\
\text { its further } \\
\text { development and } \\
\text { adaptations. } \\
\text { The use of the } \\
\text { new IS involving } \\
\text { a learning process } \\
\text { to carry out the } \\
\text { same functions in } \\
\text { a new manner, } \\
\text { resulting in } \\
\text { abundant } \\
\text { frustrations and } \\
\text { ad-hoc } \\
\text { problem-solving. }\end{array}$ & $\begin{array}{l}\text { The IS design } \\
\text { remained } \\
\text { unchanged } \\
\text { though IS has } \\
\text { been gradually } \\
\text { improved in a } \\
\text { step-by-step } \\
\text { manner. } \\
\text { Technical support } \\
\text { involves carrying } \\
\text { out minor } \\
\text { program } \\
\text { adaptations with } \\
\text { some more } \\
\text { complex tasks. }\end{array}$ \\
\hline $\begin{array}{c}\text { Integration } \\
\text { (value resulting } \\
\text { from interdepen- } \\
\text { dencies) }\end{array}$ & $\begin{array}{l}\text { Discrepancies } \\
\text { between } 5 \\
\text { different ISs. }\end{array}$ & $\begin{array}{l}\text { Larger companies } \\
\text { (A and B) } \\
\text { advocating } \\
\text { their ISs. }\end{array}$ & $\begin{array}{l}\text { The development } \\
\text { of the new IS was } \\
\text { agreed to be } \\
\text { carried out in a } \\
\text { stepwise manner, } \\
\text { beginning from } \\
\text { purchase } \\
\text { registration and } \\
\text { sales updated } \\
\text { with finished } \\
\text { product inventory } \\
\text { lists and } \\
\text { calculations of } \\
\text { sales profitability. }\end{array}$ & $\begin{array}{l}\text { IS provisional } \\
\text { functioning } \\
\text { ("barebone } \\
\text { solution”). } \\
\text { New IS running } \\
\text { by the beginning } \\
\text { of July. } \\
\text { Much frustration } \\
\text { with newly } \\
\text { deployed IS } \\
\text { (especially } \\
\text { previous Guide } \\
\text { users), many } \\
\text { errors and the } \\
\text { need for } \\
\text { continuous } \\
\text { corrections. }\end{array}$ & $\begin{array}{l}\text { After } 3 \text { months, } \\
\text { the system was } \\
\text { well adapted to } \\
\text { UF users' needs, } \\
\text { given the time } \\
\text { constraints. } \\
\text { The increase in } \\
\text { creation and use } \\
\text { of electronic } \\
\text { communications } \\
\text { and documents. } \\
\text { Difficulties in } \\
\text { linking } \\
\text { production } \\
\text { facilities, } \\
\text { especially } \\
\text { barcode scanners } \\
\text { and labelling, to } \\
\text { the new IS. }\end{array}$ & $\begin{array}{l}\text { New IS provides } \\
\text { "good" support } \\
\text { for UF users' } \\
\text { activities. } \\
\text { New IS is not } \\
\text { running as } \\
\text { specified in } 4.3 \\
\text { phase, covering } \\
\text { mainly sales and } \\
\text { distribution } \\
\text { information } \\
\text { needs, whereas } \\
\text { production and } \\
\text { logistics are } \\
\text { supported by } \\
\text { manual } \\
\text { communication } \\
\text { modes (fax or } \\
\text { email } \\
\text { attachments). }\end{array}$ \\
\hline $\begin{array}{c}\text { Interaction } \\
\text { (actors involved } \\
\text { in IS production: } \\
\text { transforming } \\
\text { resources } \\
\text { into value) }\end{array}$ & $\begin{array}{l}\text { A set of actors } \\
\text { from: A, B, C, D, E. }\end{array}$ & $\begin{array}{l}\text { Actors from A, } \\
\text { Actors from B, } \\
\text { Actors from C, } \\
\text { Actors from D, } \\
\text { Actors from E. }\end{array}$ & $\begin{array}{l}\text { Merger } \\
\text { administration, } \\
\text { Actor 1-financial } \\
\text { manager from B. }\end{array}$ & $\begin{array}{l}\text { UF } \\
\text { administration, } \\
\text { A1-UF corporate } \\
\text { financial officer, } \\
\text { A2-UF logistics } \\
\text { officer, } \\
\text { A3-UF financial } \\
\text { officer, } \\
\text { A4-external } \\
\text { services } \\
\text { management firm, } \\
\text { A5-Navision IS } \\
\text { agent in Norway, } \\
\text { A6-Navision } \\
\text { programmers, } \\
\text { A7-UF } \\
\text { Navision users. }\end{array}$ & $\begin{array}{l}\text { A4-external } \\
\text { services } \\
\text { management firm, } \\
\text { A5-Navision IS } \\
\text { agent in Norway, } \\
\text { A6-Navision } \\
\text { programmers, } \\
\text { A7-UF Navision } \\
\text { users, } \\
\text { A8-UF sales and } \\
\text { marketing } \\
\text { manager, } \\
\text { A9-UF Navision } \\
\text { super-user, } \\
\text { A10-UF 1st } \\
\text { Navision } \\
\text { proficient user, } \\
\text { A11-UF 2nd } \\
\text { Navision } \\
\text { proficient user. }\end{array}$ & $\begin{array}{l}\text { A4-external } \\
\text { services } \\
\text { management firm, } \\
\text { A5-Navision IS } \\
\text { agent in Norway, } \\
\text { A6-Navision } \\
\text { programmers, } \\
\text { A7-UF Navision } \\
\text { users, } \\
\text { A8-UF sales and } \\
\text { marketing } \\
\text { manager, } \\
\text { A9-UF Navision } \\
\text { super-user, } \\
\text { A10-UF 1st } \\
\text { Navision } \\
\text { proficient user, } \\
\text { A11-UF 2nd } \\
\text { Navision } \\
\text { proficient user. }\end{array}$ \\
\hline
\end{tabular}


The dynamics of interdependencies throughout actors' interactions in the IS development project, resulting in value integration in the new IS.

\section{References}

1. Henningsson, S.; Yetton, P.W.; Wynne, P.J. A review of IS integration in mergers and acquisitions. J. Inf. Technol. 2018, 33, 255-303. [CrossRef]

2. Wijnhoven, F.; Spil, T.; Stegwee, R.; Tjang, A.; Fa, R. Post-merger IT integration strategies: An alignment perspective. J. Strateg. Inf. Syst. 1996, 15, 5-28. [CrossRef]

3. Buck-Lew, M.; Pliskin, N.; Shaked, I.; Wardle, C. Corporate acquisitions in the 1990s: Paying attention to information technology. J. Gen. Manag. 1992, 18, 69-87. [CrossRef]

4. McKiernan, P.; Merali, Y. Integrating ISs after a merger. Long Range Plan. 1995, 28, 54-62. [CrossRef]

5. Stylianou, A.; Jeffries, C.; Robbins, S. Corporate mergers and the problems of IS integration. Inf. Manag. 1996, 31, $203-213$. [CrossRef]

6. Giacomazzi, F.; Panella, C.; Pernicci, B.; Sansoni, M. ISs integration in mergers and acquisitions: A normative model. Inf. Manag. 1997, 32, 289-302. [CrossRef]

7. Robbins, S.; Stylianou, A. Post-merger systems integration: The impact on IS capabilities. Inf. Manag. 1999, 36, 205-212. [CrossRef]

8. Alaranta, M.; Henningsson, S. An approach to analysing and planning post-merger IS integration: Insights from two field studies. Inf. Syst. Front. 2008, 10, 307-319. [CrossRef]

9. Williamson, O.E. Transaction-cost economics: The governance of contractual relations. J. Law Econ. 1979, 22, 233-261. [CrossRef]

10. Brown, C.; Renwick, J. Alignment of the IS organization: The special case of corporate acquisitions. Database Adv. Inf. Syst. 1996, 27, 25-33. [CrossRef]

11. Gaughan, P. Mergers, Acquisitions and Corporate Restructuring; Wiley: Hoboken, NJ, USA, 1996.

12. Alm, K.; Engelseth, P.; Karlsen, A. Discourses from implementing ICT systems in corporate merger--A case study from the Norwegian fish export industry. In System Dynamics and Innovation in Food Networks (Proceedings of the 3rd International Forum on System Dynamics and Innovation in Food Networks); Frits, M., Rickert, U., Schiefer, G., Eds.; Universität Bonn-ILB Press: Bonn, Germany, 2009; ISBN 978-3-941766-00-6.

13. Foucault, M. The Archaeology of Knowledge, Original French version 1969; Routledge: Milton Park, UK, 1989.

14. Latour, B. Science in Action: How to Follow Engineers in Society; Open University Press: Milton Keynes, UK, 1987.

15. Janusz, A.; Bednarek, A.; Komarowski, L.; Boniecki, P.; Engelseth, P. Networked Interdependencies and Interaction in a Biotechnology Research Project. IMP J. 2018, 12, 460-482. [CrossRef]

16. Thompson, J.D. Organizations in Action; McGraw Hill: New York, NY, USA, 1967.

17. Bizzi, L.; Langley, A. Studying processes in and around networks. Ind. Mark. Manag. 2012, 41, 215-223. [CrossRef]

18. Orlikowski, W.J.; Yates, J.A. It's about time: Temporal structuring in organizations. Organ. Sci. 2002, 13, 684-700. [CrossRef]

19. Parsons, T. Structure and Processes in Modern Society; Free Press of Glencoe: New York, NY, USA, 1960.

20. Ford, D.; Mouzas, S. Networking under uncertainty: Concepts and research agenda. Ind. Mark. Manag. 2010, 39, 956-962. [CrossRef]

21. Mehta, M.; Hirschheim, R. Strategic alignment in mergers and acquisitions: Theorizing IS integration decision making. J. Assoc. Inf. Syst. 2007, 8, 143-174. [CrossRef]

22. Gadde, L.-E.; Håkansson, H.; Persson, G. Supply Network Strategies; Wiley: Hoboken, NJ, USA, 2010.

23. Fawcett, S.E.; Mangan, G.M.; McCarter, M.W. Benefits, barriers, and bridges to effective supply chain management. Supply Chain. Manag. Int. J. 2008, 13, 35-48. [CrossRef]

24. Håkansson, H.; Johanson, J. The network governance structure: Interfirm cooperation beyond markets and hierarchy. In G. Grabher the Embedded Firm: On the Socioeconomics of Industrial Networks; Routledge: London, UK, 1993.

25. Cantu, C.; Corsaro, D.; Snehota, I. Roles of actors in combining resources into complex solutions. J. Bus. Res. 2012, 65, 139-150. [CrossRef]

26. Stabell, C.B.; Fjeldstad, Ø.D. Configuring value for competitive advantage: On chains, shops, and networks. Strateg. Manag. J. 1998, 19, 413-437. [CrossRef]

27. Pettigrew, A.M. What is processual analysis? Scand. J. Manag. 1997, 13, 337-348. [CrossRef]

28. Van De Ven, A.H.; Poole, M.S. Explaining development and change in organizations. Acad. Manag. Rev. 1995, 20, 510-540. [CrossRef]

29. Halinen, A.; Medlin, C.J.; Törnroos, J.-Å. Time and process in business network research. Ind. Mark. Manag. 2012, 41, $215-223$. [CrossRef]

30. Ellram, L.M. The use of the case study method in logistics research. J. Bus. Logist. 1996, 17, 93-138.

31. Eisenhardt, K.M. Building theories from case study research. Acad. Manag. Rev. 1989, 14, 532-550. [CrossRef]

32. Thomas, G. How to Do Your Case Study; Sage: London, UK, 2015.

33. Available online: https://pubs.opengroup.org/architecture/togaf8-doc/arch/toc.html (accessed on 1 July 2021).

34. Available online: https:/ / ec.europa.eu/isa2/eif_en (accessed on 1 July 2021). 